\title{
The match between microbial community structure and soil properties is modulated by land use types and sample origin within an integrated agroecosystem
}

\author{
Francy Junio Gonçalves Lisboa ${ }^{a}$ * , Guilherme Montandon Chaer ${ }^{\mathrm{b}}$, \\ Marcelo Ferreira Fernandes ${ }^{c}$, Ricardo Luis Louro Berbara ${ }^{a}$, Beata Emoke Madari ${ }^{\mathrm{d}}$ \\ a Soil Science Department, Agronomy Institute, Federal Rural University of Rio de Janeiro, Seropédica, RJ, 23890000, Brazil \\ b Embrapa Agrobiology (Embrapa Agrobiologia), Seropédica, RJ, 23890-000, Brazil

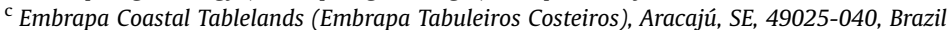 \\ ${ }^{\mathrm{d}}$ Embrapa Rice and Beans (Embrapa Arroz e Feijão), Santo Antônio de Goiás, GO, 75375-000, Brazil
}

\section{A R T I C L E I N F O}

\section{Article history:}

Received 26 May 2014

Received in revised form

26 July 2014

Accepted 27 July 2014

Available online 10 August 2014

\section{Keywords:}

Management

Tree-based systems

Agroecosystems

Microbial community

Procrustean association metric

\begin{abstract}
A B S T R A C T
It is of global concern to adopt measures to mitigate land degradation caused by agricultural production systems. One of the strategies proposed is to replace degraded pastures with agrosilvopastoral systems which integrate three different land-use types: crop production, livestock pasture and forestry plantation (denoted iCLF). However, little is known about the differences between iCLF and other land use types in terms of soil microbial community structure. Distance matrices based on individual soil chemical properties and individual soil microbial variables were correlated by Procrustes analysis and these relationships yielded vectors of residuals depicting these correlations (matches). These vectors were used as univariate response variables in an ANOVA framework in order to investigate how the match sizes (the strength of correlation/covariance) between individual soil chemical properties and individual soil microbial variables vary across land use types (levels: iCLF; degradated pasture; improved pasture; and a native cerrado fragment) and also across sample origin within ICLF (levels: soil samples under more influence of the exotic tree forest stand; soil samples under influence of the pasture; samples within the transition between the forest stand and the pasture). We were able to obtain insights into the fact that the land use distinction can be driven by more than just individual soil chemical and microbial variables. The integration of crop, livestock and forestry promoted a dominance of fungi in this low fertility and low $\mathrm{pH}$ environment. $\mathrm{P}$ availability and the composite variable exchangeable base cations $\left(\mathrm{Ca}^{+2}, \mathrm{Mg}^{+2}, \mathrm{~K}^{+}\right)$ were the soil properties whose strengths of correlation (match sizes) with individual microbial variables were the most affected by land use type and sampling origin within ICLF. While the strength of the correlation between soil microbial structure variables and $\mathrm{P}$ availability was typically land use type dependent, the response of the microbial structure to exchangeable base cations was mainly affected by the sample origin within iCLF. Finally our results point towards the conclusion that increases in the heterogeneity of vegetation within integrated crop, pasture and forestry systems are an important driver of microbial community response to environmental changes, and may be one means by which to increase the sustainability of tropical agroecosystems.
\end{abstract}

๑) 2014 Elsevier Ltd. All rights reserved.

\section{Introduction}

Global concern with farmland degradation, usually associated with soil carbon loss, has led numerous countries to seek management strategies aimed at the restoration and sustainable use of

\footnotetext{
* Corresponding author. Tel./fax: +55 2126828045

E-mail address: agrolisboa@gmail.com (F.J.G. Lisboa).
}

such areas. In Brazil, special attention is being paid to integrated crop-livestock-forest systems (iCLFs) for replacing pastures in different stages of degradation. Approximately $12 \%$ of the Earth's land surface is covered by agricultural crops, $33 \%$ is intended for livestock, and 15\% supports exotic forest species (Giraldo et al., 2011). Pastures accumulate large quantities of carbon in the topsoil layers due to the profusion of fine roots from grasses but produce relatively less recalcitrant substrates compared to forest systems. This favors organic matter mineralization by stimulating a 
microbial structure with a higher activity (Bardgett and McAlister, 1999) consequently inducing higher soil carbon losses (Millard and Singh, 2009). A recent study showed that vegetation homogenization generated by converting natural forests into pastures may be accompanied by homogenization of the microbial communities (Rodrigues et al., 2013), most likely due to a reduced diversity of good quality substrates per soil volume (Lamb et al., 2010). In contrast, the introduction of tree species may promote microbial diversity when converting pastures into exotic species forests (Carson et al., 2010).

It is believed that changes in microbial community structure generated by modified land management and land use type can be related to the soil switching from carbon source to carbon sink or vice versa. Additionally, it is suggested that land use types considered to be more conservative regarding organic matter mineralization tend to exhibit a microbial structure with lower activity (Bardgett and McAlister, 1999). Within this formulation, iCLF systems, which combine crop production, managed pasture and forest species, are designed to exhibit a microbial structure distinct from that of degraded pastures via plant physiological heterogenization of the landscape. However, soil microbial community structure is rarely investigated in agrosilvopastoral systems such as iCLF systems, especially in the tropics (Lacombe et al., 2009; Vallejo et al., 2012). Thus, we do not have a large body of evidence that iCLF systems may be more carbon conservative.

Changes that occur in vegetation composition due to land use type conversion are responsible for most of the variation that occurs in chemical and physical soil properties. In turn, these changes tend to correlate with variation in the microbial community, linking the changes above and below the soil surface (Mitchell et al., 2010; Lisboa et al., 2012). However, the extent to which this link between soil chemical variables and the phenotypic structure of the microbial community is partitioned among different land use types, as well as how the human-induced plant heterogeneity, introduced by the forest component in the integrated crop-livestock-forest (iCLF), is able to differentiate it from the other land use types, remain unaddressed questions.

In this study, we started with the hypothesis that introducing iCLF as a replacement for degraded pastures leads to a change in the response of the phenotypic composition of the soil microbial community to individual soil chemical variables. We accessed the individual responses of soil and microbial phenotypic variables to land use type in three different scenarios: 1) considering all samples in the iCLF, 2) considering only samples from the centre of the pasture component of the iCLF; 3 ) considering only samples from the forest stand within the iCLF.

For the main point in this study, i.e. how the matches/effects of individual soil chemical variables on the individual microbial variables are partitioned by land use type and sampling origin within the iCLF, we used features from Procrustes analysis (Gower, 1971). Similar to the more traditional Mantel test, Procrustes analysis is a correlative multivariate approach. However the correlation in Procrustes analysis is reached through rotation and translation, seeking for the "best" fit that depicts the minimal residual difference between homologous coordinates of two or more matrices under analysis (Peres-Neto and Jackson, 2001; Lisboa et al., 2014). These homologous coordinates are nothing but the rows (sites, samples) of the matrices under analysis so that low residuals stand for strong matches/effects whereas high residual differences mean weak matches/effects. Procrustes has the feature of providing the matches among all homologous coordinates of matrices under analysis in a vectored form sometimes called the Procrustean association metric (Lisboa et al., 2014). Thus this vector can be retained for using in downstream statistical approaches in order to investigate the consistencies in the size of the matches across different environmental predictors. In the present study we investigated the consistency in size matches from the Procrustean association metric between distance matrices based on individual soil chemical variables and soil microbial variables in an ANOVA framework having the land use type as a factor (first ANOVA) or sample origin within the iCLF as a factor (second ANOVA).

\section{Materials and methods}

\subsection{Study area}

The study was conducted in one of the 203 technology reference units in the iCFL (http://www.cnpgl.embrapa.br/nova/silpf) of the Brazilian Agricultural Research Corporation (Empresa Brasileira de Pesquisa Agropecuária - Embrapa) on the Boa Vereda farm located in the municipality of Cachoeira Dourada, Goiás State, Brazil (Fig. 1A and B). The study site is located at $18^{\circ} 27^{\prime} 43.19^{\prime \prime} \mathrm{S}, 49^{\circ} 35^{\prime} 58.53^{\prime \prime} \mathrm{W}$ at an altitude of $484 \mathrm{~m}$ above sea level, on a clay $\left(603 \mathrm{~g} \mathrm{~kg}^{-1}\right)$ Rhodic Ferralsol (Latossolo Vermelho acriférrico típico (Brazilian Soil Classification System) or Anionic Acrustox (Soil Taxonomy)) with slopes between 0 and $15 \%$ and a mean annual rainfall of $1350 \mathrm{~mm}$ (Brasil, 1983). Four land-use types were assessed in this study (Fig. S1): 1) an iCLF system; 2) improved pasture with remnants of dry forest natural vegetation (native trees); 3) degraded pasture; and 4) a native cerrado fragment (savannah-like) exhibiting 'cerrado denso' (dense tree savannah) vegetation.

\subsection{History of land use types}

Originally, all of the sites studied were covered with 'cerrado' vegetation, within which they represented forest formations of dry forest, 'cerradão' (woodland), and 'cerrado denso'. All of the areas, except the original forest, had been deforested for more than 30 years and were maintained as pasture until recently.

\subsection{1. $i C L F$}

In 2009, the iCLF system was implemented with three rows of eucalyptus trees per stand, using 476 trees per hectare (ha), in a total area of 14.7 ha with the following management sequence: in August, the soil was plowed with a disc harrow at a cutting depth of $25 \mathrm{~cm}$, and lime was incorporated into the soil. Between October and November, the soil was prepared for planting soybean (Glycine max L. variety BRSGO 8360) and eucalyptus (Eucalyptus urograndis) with a leveling disc harrow. In October 2010, the soil was prepared again for planting corn (Zea mays L.) intercropped with brachiaria grass (Urochloa brizantha). After harvesting the corn, the soil was not mechanically turned anymore, and the brachiaria grass developed into pasture between the eucalyptus rows. The soybean crop received $300 \mathrm{~kg} \mathrm{ha}^{-1} 04-30-10(\mathrm{NPK})+\mathrm{Zn}$ formula fertilizer, the corn received $300 \mathrm{~kg} \mathrm{ha}^{-1} 08-30-10+\mathrm{Zn}$ and the eucalyptus crop received 150 and $10 \mathrm{~g} \mathrm{plant}^{-1}$ of $08-30-10+\mathrm{Zn}$ and boric acid, respectively. As maintenance fertilizer, the eucalyptus received $200 \mathrm{~kg} \mathrm{ha}^{-1}$ of simple superphosphate broadcasted and $15 \mathrm{~g} \mathrm{ha}^{-1}$ boric acid, and the pasture between the eucalyptus rows received $100 \mathrm{~kg}$ urea ha ${ }^{-1}$ and $100 \mathrm{~kg} \mathrm{ha}^{-1}$ monoammonium phosphate annually.

\subsubsection{Improved pasture}

Before the pasture was restored, it was in a situation of abandonment. In 2008, the site was restored, starting with a disc harrow. Then, lime was applied and incorporated into the soil with a leveling harrow, followed by planting Brachiaria grass that continues to grow on the site. 

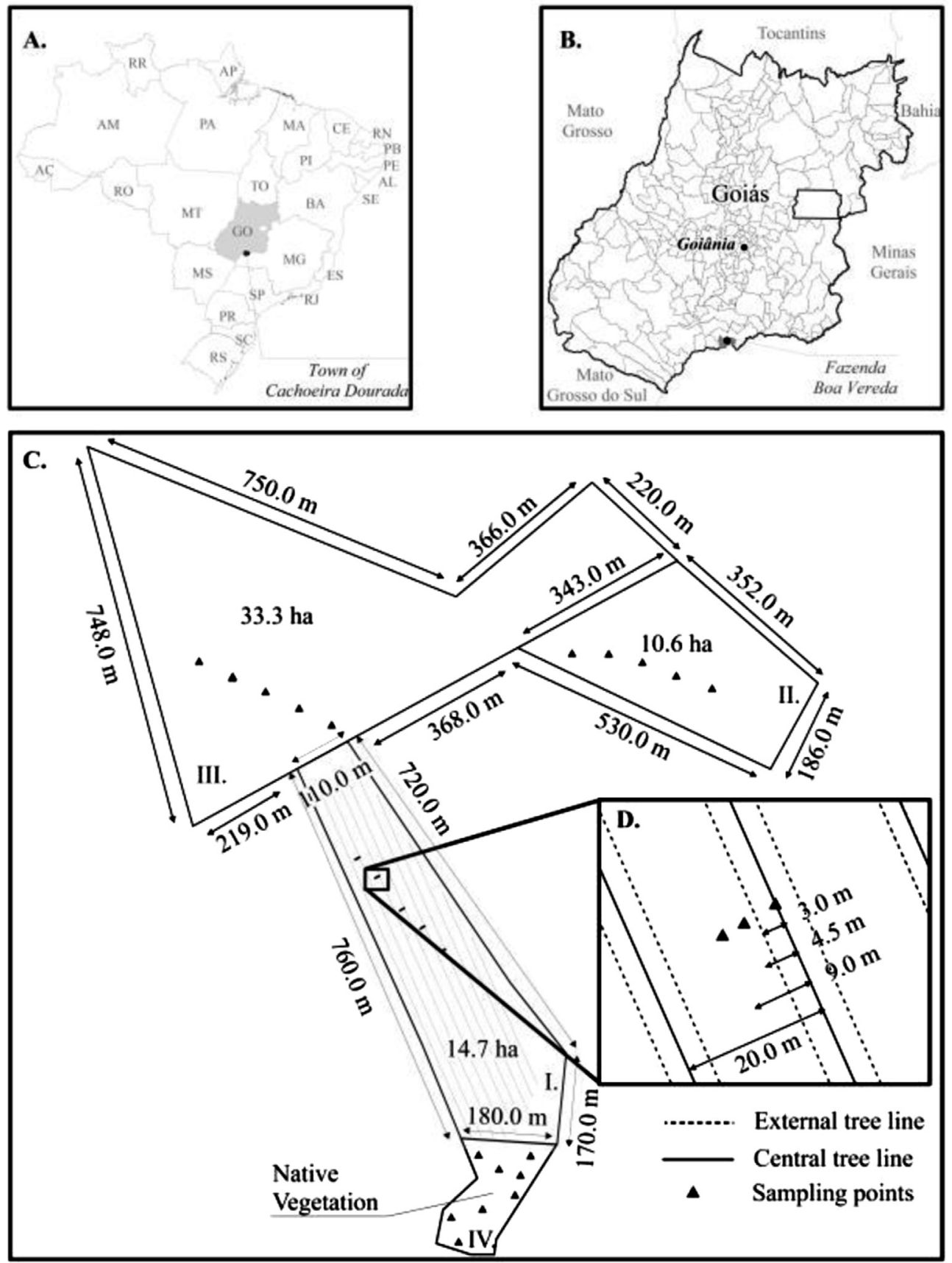

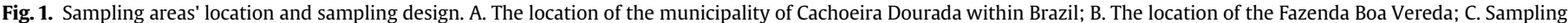

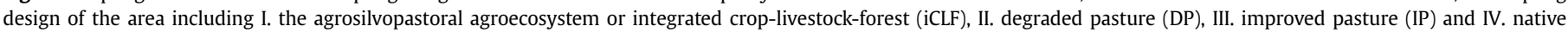

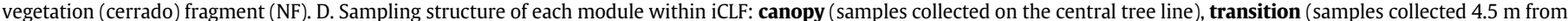
the central tree line) and outside (samples collected $9 \mathrm{~m}$ from the central tree line) sampling points. Source: Alessandra Cunha Morais (Embrapa).

\subsubsection{Degraded pasture}

This land use type occupies an area of 10.6 ha and comprises kikuyu grass (Pennisetum clandestinum) and Surinam grass (Urochloa decumbens). Lime and fertilizer were never applied.

\subsection{Sampling design}

The samples were collected in March 2012. Five sample modules were established within each land use type $50 \mathrm{~m}$ apart from each other diagonally. Except for the native cerrado fragment (NF), where eight samples were collected without using sample modules, three sampling points comprising six cores taken randomly $(5 \times 5 \mathrm{~cm})$ were collected from each sample module within degradated pasture (DP), improved pasture (IP), and iCLF (Fig. 1C). Thus, the total number of samples for each land use type was 15 (DP, IP and iCLF) and 8 (NF), which gave a sample size of 53. Specifically for the human-induced plant heterogeneity created after the introduction of the exotic tree species stands (E. urograndis) within the pasture (main feature of the iCLF), each sample within a given sample module was coming from a different origin. Here, a sample origin designation similar to that employed by Vallejo et al. (2012) was used; the sampling points taken within the 
tree component of the iCLF system were named canopy, the sampling points taken from the crown projection were named transition, and finally, the sampling points taken from the center of the pasture component of the iCLF system were named outside (Fig. 1D). So, the total 15 samples within the iCLF could be divided according to the origin: canopy (5), transition (5) and outside (5).

\subsection{Soil variables analysis}

Soil pH was determined in water and potassium chloride $(\mathrm{KCl})$ using potentiometry (Thomas, 1996). Phosphorus (P), calcium $\left(\mathrm{Ca}^{2+}\right)$, magnesium $\left(\mathrm{Mg}^{2+}\right)$ and potassium $\left(\mathrm{K}^{+}\right)$were extracted by a dilute solution of strong acids $\left(0.05 \mathrm{~mol} \mathrm{~L}^{-1} \mathrm{HCl}+0.0125 \mathrm{~mol} \mathrm{~L}^{-1}\right.$ $\mathrm{H}_{2} \mathrm{SO}_{4}$; Mehlich I) as described by Kuo (1996). Phosphorus was determined by the colorimetric method (Embrapa, 2009), $\mathrm{Ca}^{2+}$ and $\mathrm{Mg}^{2+}$ by atomic spectroscopy and $\mathrm{K}^{+}$by flame emission spectrometry (Wright and Stuczynski, 1996). Soil organic matter (SOM) was determined by the Walkley-Black method (Nelson and Sommers, 1996) without external heating, using sulfuric acid $\left(\mathrm{H}_{2} \mathrm{SO}_{4}\right)$ to create internal heat for the reaction. Soil moisture was determined gravimetrically and soil bulk density using the short $(5 \mathrm{~cm})$ core method (Grossman and Reinsch, 2002).

\subsection{Microbial analysis}

Phospholipid fatty acid (PLFA) analysis was used to assess the changes in the phenotypic structure of the microbial community because this method has been shown to be effective in discriminating changes in land-use type (Kasel et al., 2008; Diedhiou et al., 2009; Cao et al., 2010). Despite its low resolution, this approach has the advantage of allowing for quantification of different and important microbial groups and indices related to soil function, such as fungi and bacteria (Frostegård et al., 2011; Wixon and Balser, 2013). To obtain the lipid profile of the soil microbial communities, we followed the method described by Fernandes et al. (2011).

The fatty acid methyl esters (FAMEs) were separated by a gas chromatograph with a flame-ionization detector (Clarum 500, PerkinElmer) using a capillary column (5\% biphenyl-95\% dimethylpolysiloxane, $25-30 \mathrm{~m}$ ) with the following program: $5{ }^{\circ} \mathrm{C} / \mathrm{min}$, from 120 to $270{ }^{\circ} \mathrm{C}$. The injector and detector temperatures were $250{ }^{\circ} \mathrm{C}$ and $280^{\circ} \mathrm{C}$, respectively. The chromatogram peaks for each sample were identified by comparing the retention times generated by commercial standards (FAME 37 47885-U and BAME 24 47080-U Sigma-Aldrich).

The area of each peak within the sample was calculated relative to the total area of the chromatogram for obtaining the percentage of PLFA within each sample (Fernandes et al., 2011). Twenty informative peaks were common for all samples and used in the analyses, the results being expressed in percentage mol (row matrix normalization of raw values). The profile of all 20 PLFAs was used as a surrogate phenotypic structure of the microbial community. Within the total profile different markers were pooled in order to obtain proxies for the following microbial groups. Gram (+) bacteria (i15:0, a15:0, 15:0, i16:0, a16:0, i17:0, a17:0, 17:0); Gram (-)

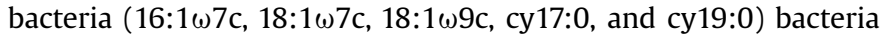
(Gram (+) plus Gram $(-)$ ); fungi $(18: 2 \omega 6,9)$; arbuscular mycor-

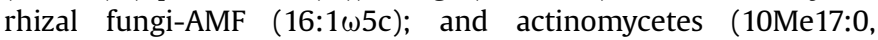
10Me16:0). The fungi: bacteria ratio (F:B ratio) was obtained by dividing the percentage mol of the 18:2 $\omega 6,9$ FAME by the sum of the percentage mol of the bacterial FAMEs. The ratios between FAMEs cy 17:0 and cy19:0 and their respective FAME precursors, $16: 1 \omega 7 \mathrm{c}$ and $18: 1 \omega 7 \mathrm{c}$, were used to measure microbial stress (Frostegård et al., 1993; Olsson, 1999; Zelles, 1999).

\subsection{Data analysis}

All of the analyses were conducted using packages available within the R statistical program (R Core Development Team, 2013). For an initial analysis of the effect of the different land-use types on the overall phenotypic variation of the microbial community, the FAMEs profile (percentage mol) was subjected to PERMANOVA (Anderson, 2001). To evaluate whether the differences in microbial structure remained consistent across samples from different sampling points of the iCLF system, we conducted three distinct PERMANOVA's: 1) considering all of the samples, independent of their origin within the iCLF; 2) only considering the samples from the center of the pasture within the iCLF (outside); and 3) only considering the samples obtained in the tree stand within the iCLF (canopy). PERMANOVA was conducted using the adonis() function of the vegan package (Oksanen et al., 2013).

We used between-group analysis (BGA) to assess visually and statistically the differences (or similarities) in microbial structure across land-use types and the potentially predominant microbial groups. Like a discriminant analysis, BGA uses scores from ordination methods as response variables and a factor with different levels as a categorical variable searching for the best combination of variables that allows the scores of the ordination axes to maximize the relationship for within- and between-level variation. In this study the scores were coming from a PCA based on a matrix of microbial groups and indices whereas the factor was the land use type (DP, IP, NF and iCLF) (Thioulouse et al., 2012). Similar to PERMANOVA, three distinct comparisons among land types using BGA were conducted based on the sample origin within iCLF: 1) considering the samples within the iCLF system; 2) only samples from exotic tree stands within iCLF (canopy); 3) only samples from the pasture within iCLF (outside). The BGA analyses were conducted using the $b c a($ ) function and the overall statistical difference among land use types was accessed by permutations using randtest.between(). These functions are available in the ade4 package (Chessel et al., 2004).

To test whether the correlations between the individual soil variables and the microbial groups and indices differ as a function of land use type, we utilized the following procedure. First, individual soil variables - except for exchangeable base cations $\left(\mathrm{Ca}^{2+}\right.$, $\mathrm{Mg}^{2+}$ and $\mathrm{K}^{+}$), as a matrix considered (EBC) - and each of the different microbial groups and indices based on percentage mol FAMEs were $\log (x+1)$-transformed and used to construct dissimilarity matrices (Euclidean). In the second step, each microbial distance matrix was related to each matrix of the individual soil variables to answer to the general question of whether the environmental distances based on individual soil variables are significantly related to the environmental distances based on different microbial groups and indices. Two analogous approaches were used: the partial Mantel test (Legendre and Legendre, 2012) and the partial PROTEST (Peres-Neto and Jackson, 2001), where both isolated the effect of the soil covariates before conducting the relationship analysis. Finally, since PROTEST (Procrustes analysis) has the feature of providing the relationship between matrices in a vectored form (Peres-Neto and Jackson, 2001) we used the vectors from significant results of the partial PROTEST in two different a one-way ANOVAs. This vector is made up by the residuals which are linking the two matrices under analysis so that the higher the residual size, the lower is the correlation/covariance. Here the vectors representing significant correlation/covariance between the distance matrices based on the individual soil chemical and the distance matrices based on microbial groups and indices were used as univariate response variables in two different one-way ANOVAs, the first one using land use type as factor (DP, IP, NF and iCLF), and the second one using the sample origin within iCFL as factor 
(canopy, transition, outside). Thus, one can assess if the heterogeneity generated by introducing exotic tree species into the pasture is able to affect the extent to which different soil variables influence microbial structure. The partial Mantel test and partial PROTEST were conducted using the vegan package (Oksanen et al., 2013), whereas the test of means was conducted using the agricolae package in $\mathrm{R}$ (Mendiburu, 2014).

\section{Results}

\subsection{Individual soil variable correlations}

The correlation plots between individual soil variables showed that the use of samples from different origins within the iCLF may be influential. The general trend was that in the scenarios using all and only samples from the planted tree stands the correlations were positive and relatively strong, particularly between soil variables $\mathrm{K}, \mathrm{Ca}$ and $\mathrm{Mg}$ and between these and $\mathrm{pH}$ (Fig. 2a and b). On other hand, the use of samples coming from the centre of the pasture within iCLF gave more negatively and moderately strong relationships, particularly the correlation of moisture and bulk density with the exchangeable base cations such as $\mathrm{K}, \mathrm{Ca}$ and $\mathrm{Mg}$ (Fig. $2 \mathrm{a}-\mathrm{c}$ ). The $\mathrm{pH}$ was positively correlated with all exchangeable base cations across all sampling origin scenarios (Fig. 2a-c). Moreover it is relevant to highlight that within the exchangeable base cations the correlations were positive from moderately to strong across the three sampling origin scenarios investigated (Fig. 2a-c), which justifies the use of the composite variable EBC. The soil organic matter related weakly with other soil variables across all the different scenarios (Fig. $2 \mathrm{a}-\mathrm{c}$ ).

\subsection{Land use ordination based on soil variables}

The principal component ordination based on soil variables was done to give an intuitive picture of general differences among land use type across the different scenarios of sampling origin within the iCLF. Across all scenarios the overall trend was the grouping of iCLF and degradated pasture (DP) and their distance from the improved pasture (IP) and native fragment (NF) (Fig. 3a-c). This general pattern seemed to be mainly driven by the contrasts in terms of the bulk density, which was higher in ICLF and DP than in the IP and NF (Fig. $3 a-c)$. In the first two scenarios of sampling origin within iCLF (all samples and canopy) the land use types iCLF, DP and IP were found to have low soil fertility when compared to NF (Fig. 3a and b). However when only samples from the centre of the pasture within the iCLF (outside) were considered the IP had a higher fertility than iCLF and DP (Fig. 3c). It is important to notice that only soil variables related significantly $(P<0.05)$ with the ordination axes are showed. Thus, SOM did not have a great contribution for the land use type discrimination as it was not related to the axes across all scenarios investigated.

3.3. Individual variables - based pairwise dissimilarity as affected by land use and sample origin within iCLF (PERMANOVA)

With the exception of the Gram (+) bacterial profile, the PERMANOVA indicated significant differences between the land-use types for all of the microbial groups and indices when considering all of the samples of the iCLF system (Table 1). Gram $(+)$

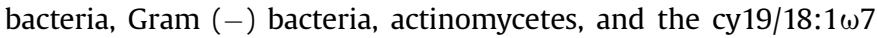
ratio were unable to differentiate the land-use types when the samples from the forest component (canopy) were considered (Table 1). However, when the pasture replicates were considered (outside), the land-use types differed based on the Gram (-) bacterial profile $(F=3.629, P<0.05)$. Additionally, the land-use types were significantly different regarding the $16: 1 \omega 5 \mathrm{c}$ marker for AMF only when PERMANOVA considered all of the samples $(F=6.701$, $P<0.01)$ and those from the forest component of the $\operatorname{iCLF}(F=4.151$, $P<0.05)$. Interestingly, the land-use types remained distinct for the general microbial, bacterial, and fungal profiles and for the F:B and cy17:0/16 ratios, regardless of microbial sample origin (Table 1). Regarding the soil variables, $\mathrm{pH}\left(\mathrm{H}_{2} \mathrm{O}\right.$ and $\left.\mathrm{KCl}\right)$, available phosphorus $(\mathrm{P})$, and soil organic matter, these parameters were unable to discriminate the land-use types across all scenarios of sampling within the iCLF (Table 1). In contrast, moisture, bulk density, and exchangeable based cations were able to differentiate the land-use types regardless of the sampling origin within iCLF system (Table 1).

\subsection{Between group analyses based on microbial variables across different sampling scenarios}

The PCA generated to run the BGA was based on a matrix of microbial groups and indices. The BGA permutations reinforced the
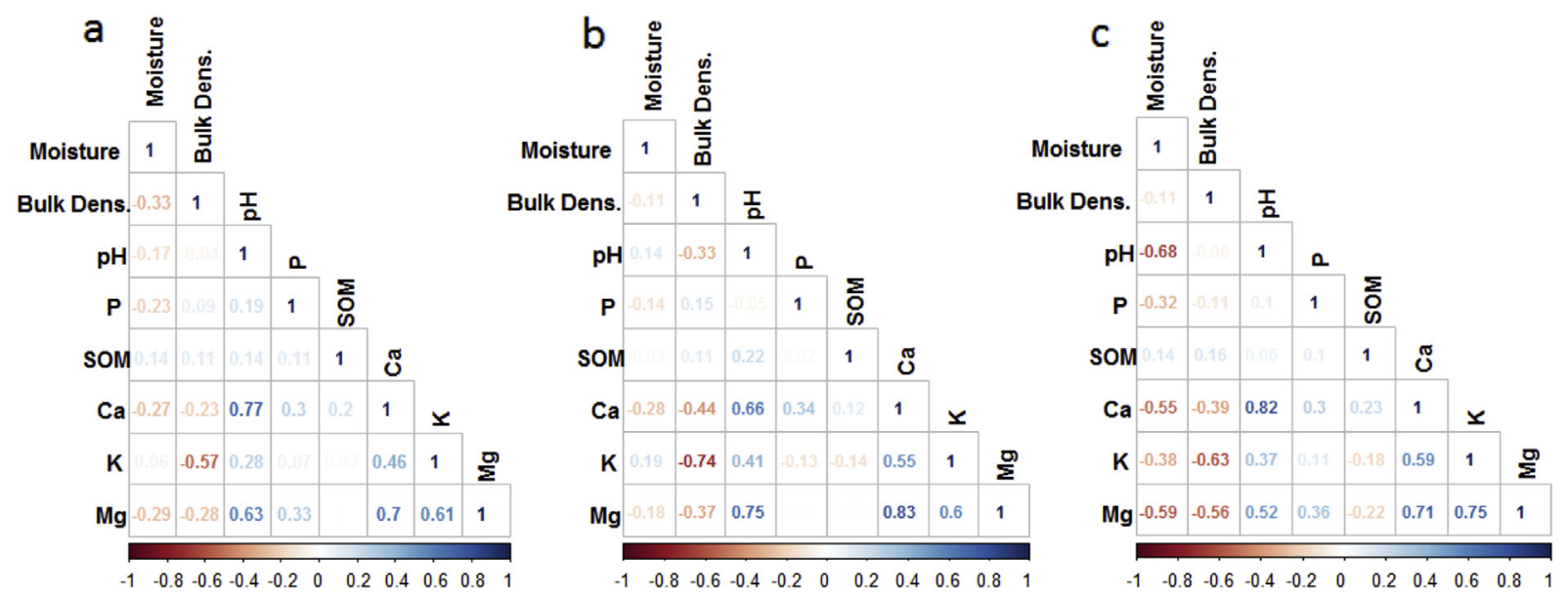

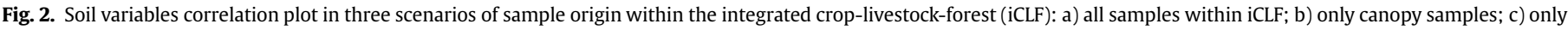

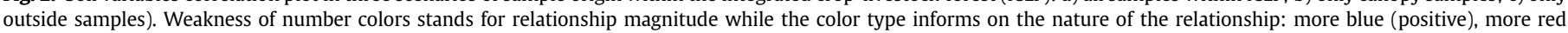

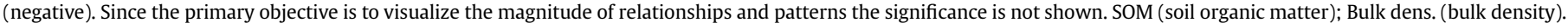

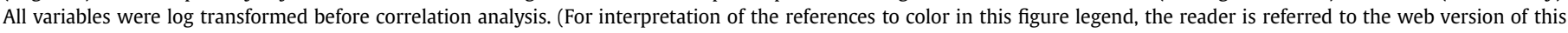
article.) 

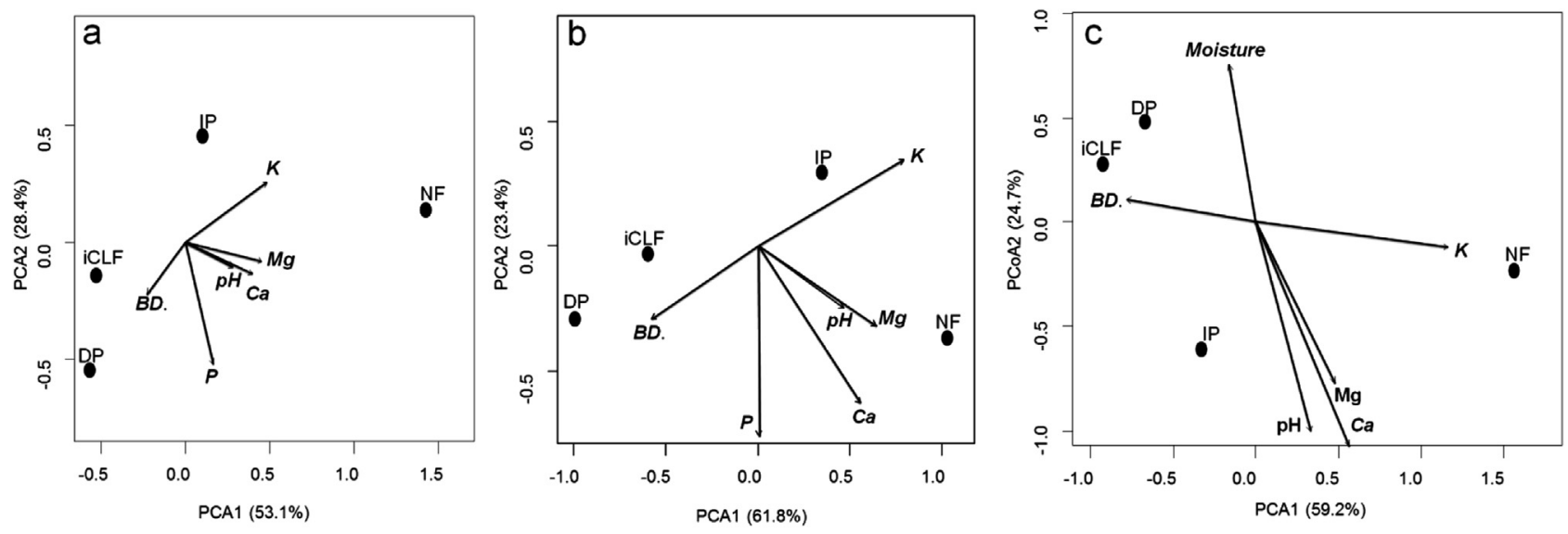

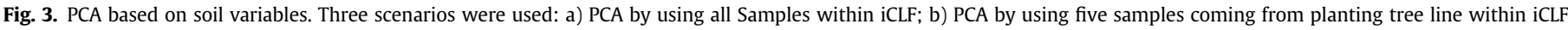

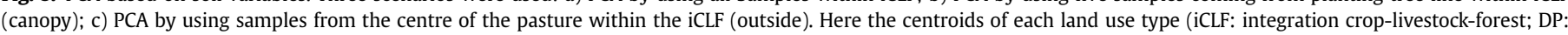

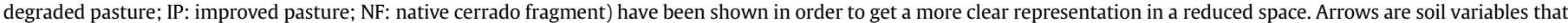
are significantly related to PCA axes $(P<0.05)$. BD (bulk density).

PERMANOVA results for soil microbial variables by showing that overall differences among land use types were not random. This was valid for all of the samples (observed value: $0.44 ; P<0.001$ ); the canopy samples (observed value: $0.53 ; P<0.001$ ); and the samples outside of the canopy (observed value: $0.49 ; P<0.001$ ).

Overall the BGA shows that across all scenarios of sampling origin within iCLF there was a trend of grouping iCLF and IP contrasting with other land use types (DP and NF) (Fig. 4a-c). Moreover, the distinction of ICLF and IP from DP and NF seems to be

Table 1

PERMANOVA. Analyses using microbial groups and indices (\% mol FAMEs) and individual soil variables as responses and land-use type as a categorical predictor (4 levels ${ }^{\Delta}$ ).

\begin{tabular}{|c|c|c|c|c|c|c|}
\hline & \multicolumn{2}{|c|}{ Samples (All) $)^{\mathrm{a}}$} & \multicolumn{2}{|c|}{ Samples (Canopy) ${ }^{\mathrm{b}}$} & \multicolumn{2}{|c|}{ Samples (Outside) } \\
\hline & $F$ & $P$ & $F$ & $P$ & $F$ & $P$ \\
\hline \multicolumn{7}{|l|}{ PLFA variables } \\
\hline PLFA profile & 14.57 & $* * *$ & 6.368 & $* * *$ & 8.387 & $* * *$ \\
\hline $\operatorname{Gram}(+)$ & 2.847 & ns & 0.730 & ns & 2.701 & ns \\
\hline $\operatorname{Gram}(-)$ & 5.576 & $* * *$ & 2.448 & ns & 3.629 & $*$ \\
\hline Bacterial & 30.58 & $* * *$ & 15.23 & $* * *$ & 13.65 & $* * *$ \\
\hline Fungal & 32.12 & $* * *$ & 15.87 & $* * *$ & 12.66 & $* * *$ \\
\hline Actinomycetes & 8.465 & $* *$ & 2.839 & ns & 3.177 & ns \\
\hline $\mathrm{AMF}$ & 6.709 & $* *$ & 4.157 & $*$ & 1.173 & ns \\
\hline $\mathrm{F}: \mathrm{B}$ ratio & 32.82 & $* * *$ & 16.47 & $* * *$ & 12.01 & $* * *$ \\
\hline 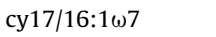 & 18.70 & $* * *$ & 8.424 & $* *$ & 8.781 & $* *$ \\
\hline 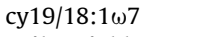 & 11.68 & $* * *$ & 0.804 & ns & 1.607 & ns \\
\hline \multicolumn{7}{|l|}{ Soil variables } \\
\hline Moisture & 19.31 & $* * *$ & 12.13 & $* * *$ & 4.952 & $*$ \\
\hline Bulk density & 22.36 & $* * *$ & 10.766 & $* * *$ & 7.978 & $* *$ \\
\hline $\mathrm{pH}\left(\mathrm{H}_{2} \mathrm{O}\right)$ & 1.921 & ns & 0.863 & ns & 1.234 & ns \\
\hline $\mathrm{pH}(\mathrm{KCl})$ & 2.868 & $*$ & 0.571 & ns & 0.523 & ns \\
\hline $\begin{array}{l}\text { Exchangeable } \\
\text { base cations }\end{array}$ & 18.43 & $* * *$ & 11.62 & $* * *$ & 17.21 & $* * *$ \\
\hline P available & 2.600 & ns & 0.555 & ns & 1.473 & ns \\
\hline Soil organic matter & 1.284 & ns & 1.651 & ns & 0.819 & ns \\
\hline
\end{tabular}

$\Delta$ : Integration crop-livestock-forest (iCLF); degraded pasture; improved pasture, native cerrado fragment.

$* P<0.05 ; * * P<0.01 ; * * * P<0.001$. ns: Not significant $(P>0.05)$. Exchangeable base cations: distance matrix based on the matrix make up by $\mathrm{Ca}^{2+}, \mathrm{Mg}^{2+}$ and $\mathrm{K}^{+}$.

a Analyses considering all of the samples from the integrated system (iCLF) regardless of origin within iCLF.

b Analyses conducted considering only the samples from the forest planting within the iCLF system (Canopy).

${ }^{c}$ Analyses conducted considering only the samples from the center of the pasture within the iCLF system. All of the PERMANOVAs were conducted using the Euclidean distance of the $\log (x+1)$-transformed data. driven by contrasts between Fungal and Bacterial variables along the highest variation axis (Fig. $4 a-c$ ).

\subsection{The access and significance of the partial protest matches}

Despite partial PROTEST to be the ground of the present study we have ran partial Mantel just like a "devil's advocate" in order to check for consistency of the effect of individual soil variables on microbial variables. Thus, we did not intend to make formal comparisons between these two approaches since it has been done elsewhere (Peres-Neto and Jackson, 2001). Considering the results of the partial PROTEST, overall microbial structure profile (PLFA), overall bacterial profile, Gram (-) bacteria, fungi, F:B and cy19:0/ $18: 1 \omega 7 \mathrm{c}$ ratios were affected by all of the soil variables included in the study (Table 2). It worthwhile to notice that the exchangeable base cations composite variable (EBC) was unique in showing a consistent significant effect on the microbial community and indices throughout both partial Mantel and partial Procrustes (Table 2). In general, the matches of the PLFA 18:2 $\omega 6,9$ (fungi) and the $\mathrm{F}: \mathrm{B}$ ratio to soil variables were similar.

\subsection{The analysis of the partial PROTEST matches in ANOVA framework}

Despite the 39 significant relationships of soil variables with microbial groups and indices identified by the partial PROTEST (Table 2), only 13 were detected by ANOVA as being significantly affected by variation in land-use type (Table 2).

None of the significant effects of the moisture and of the bulk density on microbial variables given by partial PROTEST were affected by land use type (Table 2). Within the set of the significant effect (match: correlation/covariance) of $\mathrm{pH}$ on microbial variables, the effects on Bacterial, F:B ratio, total PLFA profile and Gram (-) had their magnitude partitioned by land use type (Table 2). The post hoc test revealed these land use affected matches were generally lower in the iCLF system and degraded pasture compared to the effects in the improved pasture (IP) and in the native cerrado fragment (NF) (Fig. 5). For the exchangeable base cations variable matches affected by land use type (Table 2), the effect of this composite variable on the Gram (-) only differed between DP and NF land uses (Fig. 5). On other hand the effect of EBC on cy19/pre were higher in the DP and CLF when compared to NF and IP land use types (Fig. 5). 

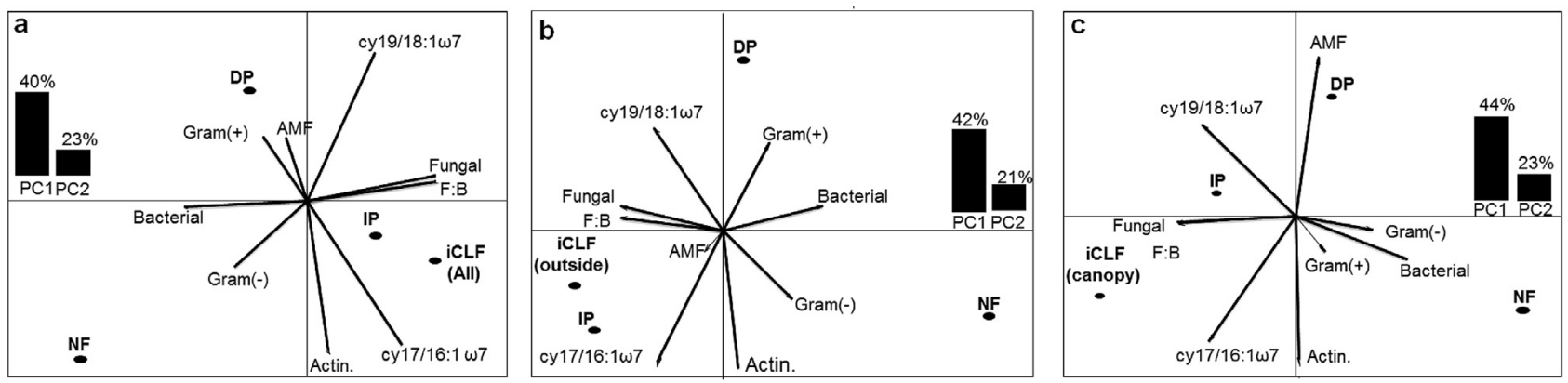

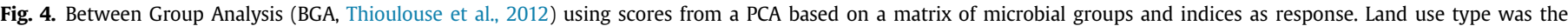

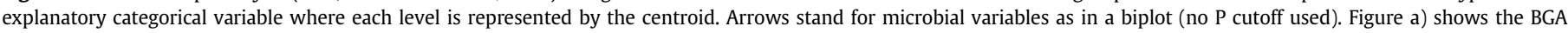

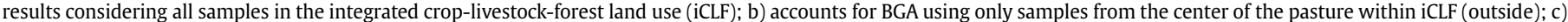

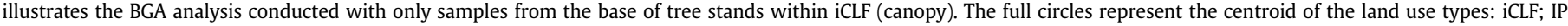

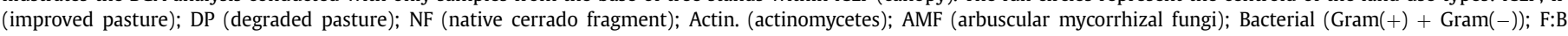
(Fungal:Bacterial ratio). Filled bars indicate the variation explained by the first two principal axes.

The significant matches between $P$ and microbial variables were all affected by the land use type (Table 2 ). A clear pattern was found given that the effect of the $\mathrm{P}$ on microbial structure variables was consistently low in iCLF (Fig. 6).

\subsection{The partitioning of the soil chemical - soil microbial match sizes across sample origin within}

The 39 significant relationships provided by the partial PROTEST from Table 2 were again subjected to ANOVA, but now considering the sample origin within the iCLF as a three level factor (canopy, transition, outside). Only the effects of the exchangeable base cations variable $(E B C)$ on microbial variables were affected by the sample origin, namely its effects on the Gram (-), bacteria, fungi, F:B ratio, and cy 19:0/18:1 $\omega 7 \mathrm{c}$ ratio (Table 3 ). Post hoc test revealed that all of these effects were quantitatively higher in the (canopy) than in the (transition) and (outside) (Fig. 7).

\section{Discussion}

The word "heterogeneity" used here is not related to the gradient of plant diversity across all land use types investigated. It stands for the deliberate heterogeneity (i.e. a human-induced landscape arrangement) which characterizes the integrated croplivestock-forest land use type (iCLF). This human-induced heterogeneity is mainly caused by the introduction of regular tree stands in a pasture followed by soil management. Thus this study has tried to raise relevant insights on how this introduced heterogeneity within iCLF makes this land use type distinct from others, not only by investigating individual soil chemical and microbial variables, but mainly in terms of "matches" between them. To accomplish this we ran a series of standard (PERMANOVA) and non-standard (BGA and Procrustes associated with ANOVA) statistical approaches considering different sampling origins.

\subsection{Sample origin within the iCLF system affects microbial-based land use variations}

Soil resource heterogeneity is well known as a biological diversification factor (Hodge, 2006), whereas variations in landscape characteristics due to the introduction of plant species are related to the heterogenization of different ecosystem components, including the soil microbial community (Bach et al., 2010; Carson et al., 2010). Thus, using pasture together with exotic forest species may make the iCLF system a consistent management strategy for seeking diversification of the quality of substrates offered to the soil microbial community (Vallejo et al., 2012). It is recognized that although lipid analyses have low taxonomic resolution compared to modern molecular techniques, the detailing of the microbial community into its main functional members, including fungi and bacteria, is sufficient to demonstrate that different land-use types also differ from each other in their microbial makeup (Lacombe et al., 2009; Unger et al., 2012; Vallejo et al., 2012).

Some studies have suggested that introducing tree species into pastures may increase the soil microbial diversity. Carson et al. (2010), for example, found that introducing Eucalyptus species into pastures favored the maintenance of soil fungal community diversity. Similarly, Lacombe et al. (2009) reported that microbial community stability, associated with its heterogeneity, was higher in tree-based systems. The results obtained in this study through the strategy of sequentially using samples from different sampling origins within the $\mathrm{iCLF}$ in the BGA corroborates these previous findings. In our results, fungal and bacterial variables were responsible for the main contrast between land use types in terms of microbial community structure, with iCLF and improved pasture both exhibiting a high fungal dominance trend when compared to degraded pasture and native forest. However it is not in line with the findings of Grayston et al. (2004) which observed greater fungal dominance in semi improved and unimproved pasture.

Bacteria, fungi, and the $\mathrm{F}: \mathrm{B}$ ratio were able to discriminate land use types regardless of sample origin within the iCLF system. This supports other work showing that these two groups are suitable for discriminating land use types (Strickland and Rousk, 2010). In this point it is noteworthy that the differentiation between land use types based on the Gram (-) bacterial profile and the AMF marker $(16: 1 \omega 5 c)$ was affected by sample origin within iCLF. For example, the AMF marker was unable to discriminate land use when samples from the center of the pasture within the iCLF system (outside) were considered, but was successful when the samples from the forest component of iCLF (canopy) were used. These results highlighted the sensitivity of AMF since in the iCLF system the pasture component undergoes recurring interventions such as mechanization and animal introductions, which are factors that negatively affect the AMF (Jansa et al., 2002; van Groenigen et al., 2010), whereas the tree stands within the forest component of the iCLF are not subject to the same management intensity.

The same argument used above may be used to try to explain why the land use types were discriminated by the Gram (-) bacterial profile when the samples from the center of the pasture component (outside) were considered rather than those from the tree stand (canopy). It may be due to the fact that the predominance of Gram (-) bacteria is attributed to conditions of higher 
Table 2

The significant relationships (partial Mantel and partial Protest) between distance matrices based on individual soil variables and distance matrices based on microbial groups and indices. The significant Procrustean relationships (partial Protest) in a form of vectors were used as response in a one-way ANOVA framework (factor: land use type with four levels ${ }^{\Delta}$ ).

\begin{tabular}{|c|c|c|c|c|}
\hline \multirow[t]{2}{*}{ Relationships (matches) } & \multirow{2}{*}{$\begin{array}{l}\text { Partial } \\
\text { Mantel }^{\text {Euc }}\end{array}$} & \multirow{2}{*}{$\begin{array}{l}\text { Partial } \\
\text { Protest }^{\text {Euc }}\end{array}$} & \multicolumn{2}{|c|}{ Land use (ANOVA) } \\
\hline & & & $\bar{F}$ & $P$ \\
\hline Moisture $\times$ total PLFA & $0.25 * * *$ & $0.44 * *$ & 1.030 & 0.395 \\
\hline Moisture $\times \operatorname{Gram}(-)$ & $0.16^{* *}$ & $0.30 *$ & 0.576 & 0.633 \\
\hline Moisture $\times$ Bacterial & $0.17 * *$ & $0.45^{* * *}$ & 0.703 & 0.555 \\
\hline Moisture $\times$ Fungal & ns & $0.47 * * *$ & 0.974 & 0.413 \\
\hline Moisture $\times$ AMF & ns & $0.32 *$ & 2.296 & 0.085 \\
\hline Moisture $\times$ F:B ratio & ns & $0.47 * * *$ & 0.749 & 0.528 \\
\hline Bulk dens. $\times$ PLFA & $0.19 * *$ & $0.46 * * *$ & 0.443 & 0.749 \\
\hline Bulk dens. $\times$ Gram $(-)$ & $0.15^{* *}$ & $0.35 * *$ & 0.381 & 0.767 \\
\hline Bulk dens. $\times$ Fungal & ns & $0.22 *$ & 0.892 & 0.463 \\
\hline Bulk dens. $\times$ F:B ratio & ns & $0.28 *$ & 0.923 & 0.437 \\
\hline Bulk dens $\times$ cy19/pre & $0.25 * *$ & $0.48^{* * *}$ & 0.118 & 0.949 \\
\hline $\mathrm{pH}\left(\mathrm{H}_{2} \mathrm{O}\right) \times$ total PLFA & ns & $0.38 * *$ & 2.510 & 0.070 \\
\hline $\mathrm{pH}\left(\mathrm{H}_{2} \mathrm{O}\right) \times \operatorname{Gram}(-)$ & ns & $0.28 *$ & 2.039 & 0.095 \\
\hline $\mathrm{pH}\left(\mathrm{H}_{2} \mathrm{O}\right) \times$ Bacterial & ns & $0.32 *$ & 3.841 & $0.015^{*}$ \\
\hline $\mathrm{pH}\left(\mathrm{H}_{2} \mathrm{O}\right) \times \mathrm{F}: \mathrm{B}$ ratio & ns & $0.29 *$ & 3.576 & $0.020 *$ \\
\hline $\mathrm{pH}(\mathrm{KCl}) \times$ total PLFA & ns & $0.37 * *$ & 2.841 & $0.041 *$ \\
\hline $\mathrm{pH}(\mathrm{KCl}) \times \operatorname{Gram}(-)$ & ns & $0.29 *$ & 2.768 & 0.051 \\
\hline $\mathrm{pH}(\mathrm{KCl}) \times$ Bacterial & ns & $0.32 *$ & 3.818 & $0.015^{*}$ \\
\hline $\mathrm{pH}(\mathrm{KCl}) \times$ cy $19 /$ pre & ns & $0.30 * *$ & 2.051 & 0.119 \\
\hline EBC $\times$ total PLFA & $0.34 * *$ & $0.57 * * *$ & 1.004 & 0.399 \\
\hline $\mathrm{EBC} \times \operatorname{Gram}(-)$ & $0.20 * *$ & $0.39 * *$ & 3.224 & $0.030 *$ \\
\hline $\mathrm{EBC} \times$ Bacterial & $0.20 * * *$ & $0.44 * * *$ & 0.754 & 0.525 \\
\hline EBC $\times$ Fungal & $0.20 * *$ & $0.40 * * *$ & 1.852 & 0.150 \\
\hline $\mathrm{EBC} \times \mathrm{F}: \mathrm{B}$ ratio & $0.20 * *$ & $0.40 * *$ & 1.573 & 0.208 \\
\hline EBC $\times$ cy $19 /$ pre & $0.10 *$ & $0.35^{* *}$ & 3.564 & $0.020 *$ \\
\hline $\mathrm{P} \times$ total PLFA & ns & $0.031 *$ & 3.693 & $0.017 *$ \\
\hline $\mathrm{P} \times$ Bacterial & ns & $0.28 *$ & 3.913 & $0.013 *$ \\
\hline $\mathrm{P} \times$ Fungal & $0.14 *$ & $0.34 * *$ & 3.251 & $0.029 *$ \\
\hline $\mathrm{P} \times$ Actin & ns & $0.33^{*}$ & 3.825 & $0.015^{*}$ \\
\hline $\mathrm{P} \times \mathrm{AMF}$ & ns & $0.31 *$ & 6.227 & $0.001 * *$ \\
\hline $\mathrm{P} \times \mathrm{F}: \mathrm{B}$ ratio & $0.14 *$ & $0.34 * *$ & 3.225 & $0.030 *$ \\
\hline SOM $\times$ total PLFA & $0.18^{* *}$ & $0.46^{* *}$ & 1.657 & 0.188 \\
\hline $\operatorname{SOM} \times \operatorname{Gram}(-)$ & ns & $0.33^{* *}$ & 1.823 & 0.154 \\
\hline SOM $\times$ Bacterial & ns & $0.37 * *$ & 1.177 & 0.328 \\
\hline SOM $\times$ Fungal & ns & $0.42 * * *$ & 0.353 & 0.787 \\
\hline SOM $\times$ Actin & ns & $0.31 *$ & 4.136 & $0.010^{*}$ \\
\hline $\mathrm{SOM} \times \mathrm{F}: \mathrm{B}$ ratio & ns & $0.42 * * *$ & 0.334 & 0.800 \\
\hline SOM $\times$ cy $19 /$ pre & ns & $0.31 *$ & 0.640 & 0.593 \\
\hline
\end{tabular}

Euc indicates "Euclidean", which was the resemblance measure used for building the distance matrices. Prior to calculation of dissimilarities, the variables related were $\log (x+1)$-transformed. PLFA: Fatty acid profile. Likewise, the match/effect of each soil variable distance matrix was tested after accounting for covariance with other soil variables. ${ }^{\Delta}$ Land use factor levels are: DP (degradated pasture); IP (improved pasture); NF (native cerrado fragment); iCLF (integration crop-livestock-forest). "EBC" is a composite variable referring to a data matrix make up by exchangable base cations $\left(\mathrm{Ca}^{2+}, \mathrm{Mg}^{2+}\right.$ and $\left.\mathrm{K}^{+}\right)$. Actin (actinomycetes); AMF (arbuscular mycorrhizal fungi); Bacterial (Gram(+) + Gram(-)); F:B (Fungal:Bacterial ratio); cy19/pre(

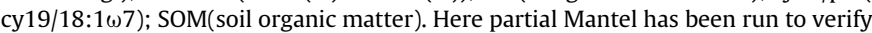
match consistencies given by partial PROTEST (main analysis). $* P<0.05 ; * * P<0.01$; $* * * P<0.001$.

resource availability (Ponder and Tadros, 2002), which are found in the pasture component of the iCLF system because fertilizer addition is a practice used when the iCLF is in the grain production phase, affecting nutrient availability in the following pasture phase as well (Bardgett et al., 2001). These results are in line with Grayston et al. (2004), which indicated differences for different levels of management quality by observing that Gram (-) bacteria were dominant within improved pasture. However, it does not necessarily mean that all iCLF is dominated by Gram (-) bacteria at all, given that our results have also indicated a fungal dominance trend within this particular land use type. It suggests that the differences in sample origin are important determinants in differentiating the iCLF from other land use types.

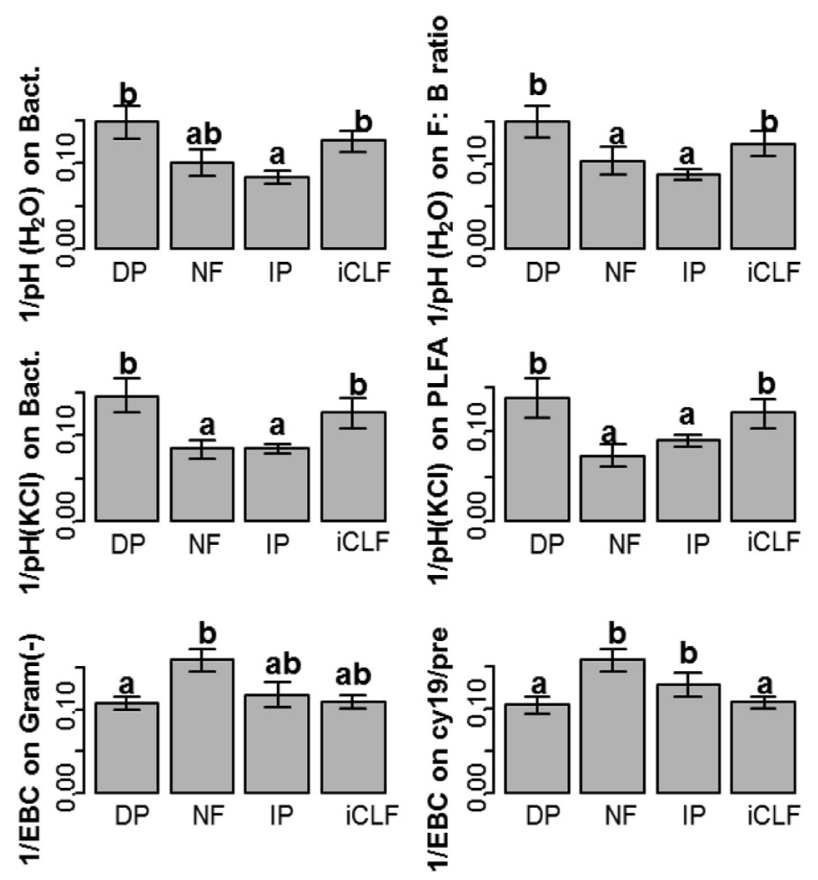

Fig. 5. Mean test (LSD, 95\%, $P$ value adjusted by Bonferroni) showing the variation in the match sizes of the $\mathrm{pH}$ and exchangeable base cations (EBC) to soil variables on microbial groups and indices as affected by the land use types. All these matches are coming from partial PROTEST (Procrustes analyses) based on Euclidian of $\log (x+1)$ dissimilarities matrices of individual variables. Here, the only effects of $E B C$ and $\mathrm{pH}$ shown are those that were considered to be affected significantly by land use type in the ANOVA (Table 2). IP (improved pasture); DP (degraded pasture); NF (native cerrado fragment), integrated crop-livestock-forest (iCLF). PLFA (general microbial profile-20 peaks); Bacterial (Gram $(-)+($ Gram $(+))$; F:B (Fungal:Bacterial ratio). The expression $1 /$ match is used because these effects are Procrustes association metrics representing the matching between individual soil chemical and soil microbial variables, which are inversely proportional to the level of relationship (or effect), so a higher value indicates a lower effect. Standard errors (SE) are shown in each bar.

Interestingly our results show that soil organic matter (SOM) was unable to differentiate the treatments, i.e., land use types (Table 1). Additionally, both the PERMANOVA analyses conducted with the canopy samples and those that used the soil from the center of the pasture (outside) in the iCLF system did not indicate SOM as a significant discriminator of land use types. It is likely due to the fact that SOM has been weakly related to other soil variables (Fig. 2a-c). Also, the PCA results based on soil variables has highlighted that SOM had no significant contribution for land use type ordination regardless in the scenario of sampling origin (Fig. $3 a-c$ ). Thus these results indicate that sample origin in iCLF is not able to discriminate from other land use types in terms of SOM, and also that the introduction of exotic tree species in the pasture has still not been able to generate contrasts in SOM within the iCLF. It corroborates results from Lai et al. (2014) who found little organic carbon variation in response to introduction of tree species into pastures. In contrast to organic matter, our results showed that the land use types were separated in all of the PERMANOVA contexts (all samples, canopy, outside) by moisture content, bulk density, and exchangeable base cations $\left(\mathrm{Ca}^{2+}+, \mathrm{Mg}^{2+}, \mathrm{K}^{+}\right)$, which suggests that the main difference of land use are associated with changes in these soil variables (Drenovsky et al., 2004; Berthrong et al., 2009). Moreover, the PCA results based on soil variables showed these variables as significantly related to ordination axes contributing towards highlighting the importance of these variables. For example, the bulk density was found to be higher in iCLF and degraded pasture (DP) than in improved pasture (IP) and native fragment (NF). Studies have indicated the influence of management 

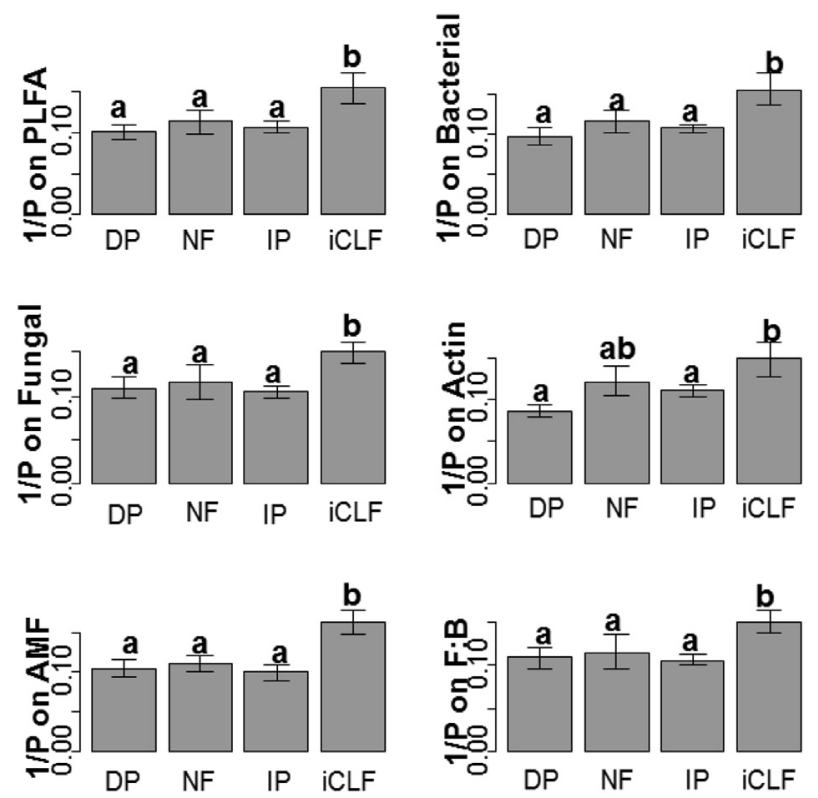

Fig. 6. Mean test (LSD, 95\%, $P$ value adjusted by Bonferroni) showing the variation in the match sizes of the $P$ to the soil variables on microbial groups and indices as affected by the land use types. All these matches are coming from partial PROTEST (Procrustes analyses) based on Euclidian of $\log (x+1)$ dissimilarity matrices of individual variables. Here, the only effects of $P$ on microbial variables shown are those that were considered to be affected significantly by land use type in the ANOVA (Table 2). IP (improved pasture); DP (degraded pasture); NF (native cerrado fragment), integrated croplivestock-forest (iCLF). PLFA (general microbial profile-20 peaks); Bacterial $(\operatorname{Gram}(-)+(\operatorname{Gram}(+)) ; \mathrm{F}: \mathrm{B}$ (Fungal:Bacterial ratio); Actin (actinomycetes); AMF (arbuscular mycorrhizal fungi). The expression 1/match is used because these effects are Procrustes association metrics representing the matching between individual soil chemical and soil microbial variables, which are inversely proportional to the level of relationship (or effect), so a higher value indicates a "lower effect". Standard errors (SE) are shown in each bar.

intensity on the bulk density, by pointing out that areas not undergoing frequent anthropic interferences tend to show lowest bulk density values as result of the accumulation of plant residues incorporated into the soils, associated with non-disturbance of structure by machines, agricultural traffic and animal trampling (Hamza and Anderson, 2005). It may explains the low bulk density in the native fragment NF and improved pasture IP since while the former is an area without any anthropic interference, the latter is subjected to a low level of mechanization and grazing pressure when compared to iCLF and DP.

The accumulation of plant residues along with the absence of management pressure can also explain the relatively higher exchangeable base cations in the native fragment (NF) than other land use types. Also it is interesting to note that in our results the improved pasture (IP) remained similar to iCLF in terms of low

Table 3

One-way ANOVA showing which of the significant matches/effects of soil variables on microbial groups and indices (PLFA) given by the partial Protest from Table 2 were affected by the sample origin within integrated crop-livestock-forest land use type (iCLF) (sample origin factor levels: canopy, transition, outside).

\begin{tabular}{|c|c|c|}
\hline \multirow[t]{2}{*}{ Relationships (matches) } & \multicolumn{2}{|c|}{ Sample origin within (iCLF) } \\
\hline & $F$ & $P$ \\
\hline $\mathrm{EBC} \times \operatorname{Gram}(-)$ & 8.618 & $0.0047 * *$ \\
\hline EBC $\times$ Fungal & 7.292 & $0.0084 * *$ \\
\hline $\mathrm{EBC} \times \mathrm{F}: \mathrm{B}$ ratio & 7.707 & $0.0070 * *$ \\
\hline 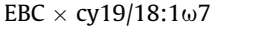 & 4.005 & $0.0400 *$ \\
\hline
\end{tabular}

$* P<0.05 ; * * P<0.01$. "EBC" is a composite variable exchangeable base cations $\left(\mathrm{Ca}^{2+}\right.$, $\mathrm{Mg}^{2+}$ and $\mathrm{K}^{+}$). F:B (Fungal:Bacterial ratio).
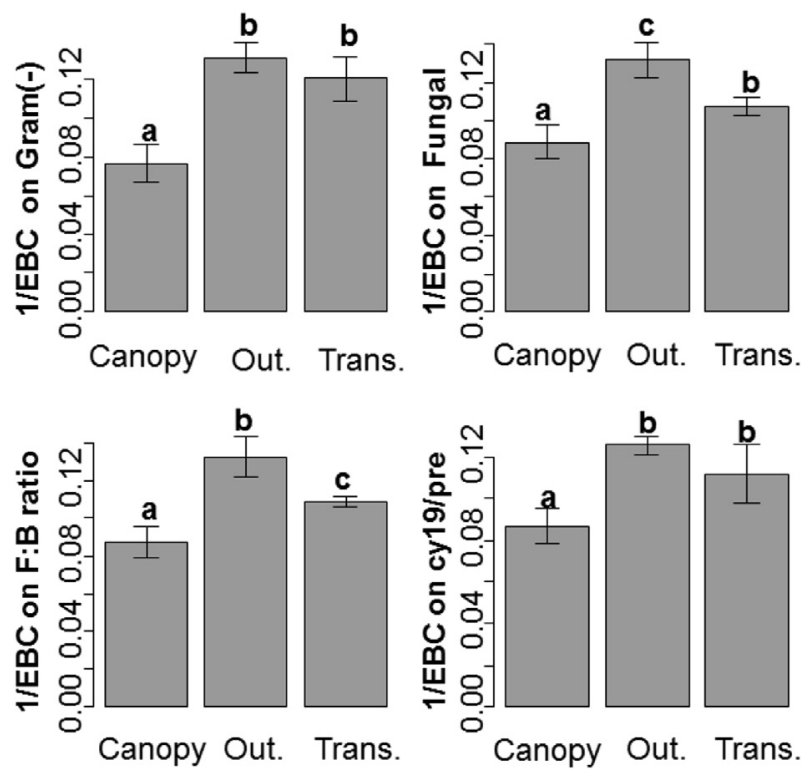

Fig. 7. Mean test (LSD, 95\%, $P$ value adjusted by Bonferroni) showing the variation in the match size between EBC and soil microbial variables and on microbial groups and indices as affected by the soil sample origin within the integrated crop-livestock-forest land use (iCLF). All these matches coming from partial PROTEST (Procrustes analyses) are based on Euclidian of $\log (x+1)$ dissimilarities matrices of individual variables. Canopy (samples from tree stand); Out (outside: samples from center of the pasture); Trans (transition: samples from canopy projection). F:B (Fungal:Bacterial ratio); cy19/

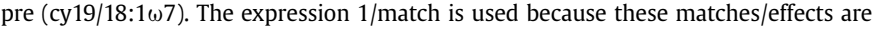
Procrustes association metrics representing the matching between individual soil chemical and soil microbial variables, which are inversely proportional to the level of relationship (or effect), so a higher value indicates a "lower effect". Standard errors (SE) are shown in each bar.

exchangeable base cations availability across the two first scenarios of sample origin (all samples and canopy samples). However these two land use types became more divergent when samples from pasture within iCLF were considered (Fig. 3a-c). These results suggest that the spatial variation in the exchangeable base cations availability within the iCLF is driven by the human-induced plant heterogeneity characterizing this land use type, as well as it influencing how the iCLF differs from the improved pasture. Thus it seems that the area under tree influence has been responsible for making the iCLF a bit closer to improved pasture (IP) in terms of exchangeable base cations than the area under most pasture influence.

\subsection{Microbial structure - soil properties "match size" variation}

The individual effects of the soil variables that normally change in response to alterations in land use type were indicated by two analogous analyses: the partial Mantel test and partial PROTEST (Procrustes analysis). The fact that the partial PROTEST provided a higher number of significant relationships between soil and microbial variables attests to the high power of this analysis approach compared to the Mantel test (Peres-Neto and Jackson, 2001).

As indicated by Procrustes analysis, the variables soil bulk density, $\mathrm{P}$ availability, moisture content and exchangeable base cations showed a significant match to the microbial structure variables (Table 2). Again it worthwhile remembering that the match size stands for the strength of the correlation/covariance between distance matrices based on individual variables. This reinforces the hypothesis that these variables were important in linking the changes in land use with the microbial community at our study site. However only a few of these matches/effects were affected by land 
use type (Table 2). For example, the matches between the composite variable exchangeable base cations (EBC) and microbial variables, namely Gram (-) and cy $19 / 18: 1 \omega 7$, were significantly affected by the land use type. This suggests that the EBC may be important, linking changes above and below ground. These results agree with the increasing evidence of the important role of exchangeable base cations as drivers of the microbial community. For example Allison et al. (2007), studying temporal and soil depth effects on microbial community structure, found that EBC was the main driver of microbial community composition.

Minerals are the primary source of EBC in the soils and it has been argued that the variation in the distributions of minerals in the soil may influence soil microbial variations (Carson et al., 2009; Reith et al., 2012). For example, Gleeson et al. (2005, 2006) showed that singular bacterial and fungal communities colonized different minerals. However, despite these interesting previous findings it is unlikely that the mineral variability is the main mechanism explaining the partitioning of the matches between the EBC and the microbial variables by the land use type. The reason for this is that the entire area encompassing all land use types investigated has the same geological formation, being characterized by an intense soil weathering, which in turn is related to a narrow clay mineral range, namely kaolinite and iron oxides. Since this scenario stands for a low natural soil fertility, it is more likely that EBC-microbial variable matches differences across land use types are due to the management history rather than geological formations. Our results showed that the EBC are high in the native fragment (NF) and low in the other land use types (Fig. 3a-c). Interestingly the NF exhibited the weaker matches between EBC and microbial variables related to fertility status as Gram (-) and cy19/18:1 $1 \omega 7$ (Ponder and Tadros, 2002; Aliasgharzad et al., 2010) when compared to the other land use types, specially DP and iCLF (Fig. 5). It suggests low starvation effects on the Gram (-) community in the NF whereas in the other man-managed land use types, specially DP and iCLF, the bacterial community seems to be more affected by the lack of resources as a result of the lower EBC exhibited.

The PCA on soil chemical variables and the correlations among individual soil chemical variables showing that $\mathrm{pH}$ was negatively linked to exchangeables base cations supports low matches of $\mathrm{pH}$ to microbial structure variables in DP and iCLF. This may be due to the high soil acidity and thus to the low nutrient availability. The relative distinctiveness of fungi and bacteria in relation to acidic environmental preferences has been well documented, with fungal communities tending to dominate in the more acidic soils than bacteria (Rousk et al., 2009; Strickland and Rousk, 2010). We found weak matches between $\mathrm{pH}$ and microbial structure variables in DP and $\mathrm{iCLF}$ (Fig. 5), and within these matches the response of $\mathrm{F}: \mathrm{B}$ ratio was a general measure of microbial shifting structure (Strickland and Rousk, 2010). Thus one would be expecting fungi to be dominant in DP and iCLF rather than in NF and iCLF. Our results indicated a fungal dominance trend in iCLF followed by IP (Fig. 4). Thus it is likely that the acidity in the DP is not associated with a fungal dominance trend but rather with a bacterial community more adapted to acidity and starvation conditions as Gram (+), which was partially supported by our results (Fig. 4a and b).

The variation in $P$ availability had significant matches with microbial structure variables and supports the importance of this nutrient as a driver of soil microbial community, especially in tropical conditions (Liu et al., 2012, 2013). Additionally the matches/ effects size between $\mathrm{P}$ and microbial structure variables were observed to be more partitioned by land use type than the matches of other soil properties (Table 2). Interestingly, the effects of $P$ on microbial variables such as F:B ratio, were less intense (weaker matches) in the iCLF than in the other treatments (Fig. 6). Although it is known that P affects the microbial community (Liu et al., 2012,
2013; Zhang et al., 2013), it is striking that these effects on the microbial community were less prominent in a unique land use type, namely iCLF, even though P availability was also low for other sites (Fig. 3). By associating these results with those reporting that iCLF has low P, low EBC (Fig. 3) and fungal dominance trend (Fig. 4), it is suggested that microbial community found in the iCLF is adapted to low resource availability (Rousk and Baath, 2007; Rinnan and Baath, 2009). We recognize, however, that resource availability is usually related to other important soil nutrients, especially N. Even so, these results highlight the importance of the $P$ in our study area, which is characterized by a high soil immobilization of this element.

\subsection{The match between exchangeable base cation and soil microbial variables within the $i C L F$}

Only the effects (match sizes: strength of correlation) of EBC on microbial structure variables were partitioned by the sampling origin within the iCLF. Clearly, the canopy and outside positions differed regarding magnitude of these effects (Fig. 7), with F:B ratio,

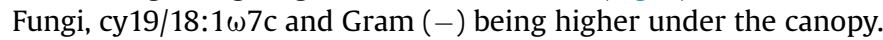
As stated the canopy represents the area under highest influence of tree plantation whereas outside is the area the under low influence of the tree component. We have discussed in previous sections that the outside samples within the iCLF made this land use type more distinct from improved pasture in terms of EBC availability whereas the canopy samples made these two a bit closer as showed by PCA results (Fig. $3 a-c)$. It indicates that the canopy and outside samples within iCLF differ in EBC suggesting that the human-induced plant heterogeneity within iCLF may be shifting the soil microbial community structure by changing their response to base cations (Diedhiou et al., 2009; Bach et al., 2010; Carson et al., 2010).

\section{Conclusions}

It is important to stress that despite interesting insights raised by this study, any temporal was not carried out. More studies are needed to address spatial and temporal consistencies of the land use type effects on the matches between microbial community and soil properties. Even so, the use of the Procrustean metric associated with downstream statistical approaches may open an interesting avenue for soil microbial ecologists, as it allows them to put the correlation as a central object of study either as response or predictor. In the present case by using the Procrustes association metric in the ANOVA framework, we were able to show that the land use type distinction can be driven not just by individual soil chemical and microbial variables. The partitioning of the match sizes (correlation/covariance) between soil chemical and microbial variables across land use types was useful in showing that iCLF is an environment with low $\mathrm{pH}$ and fertility and with a trend to fungal dominance. Furthermore, we gained insights that both P and EBC are the most important soil chemical variables linking changes above and below ground. However, while the responses of microbial structure to the $\mathrm{P}$ are more land use type dependent, the effects of $\mathrm{EBC}\left(\mathrm{Ca}^{+2}, \mathrm{Mg}^{+2}, \mathrm{~K}^{+}\right)$on microbial community variables are mainly affected by the samples origin within iCLF, which is associated to vegetal heterogeneity in this agroecosystem. Thus our results indicate that increases in the heterogeneity of vegetation by integrated crop, pasture and forestry systems are an important driver of microbial community response to environmental changes and may be one means to increase the sustainability of tropical agroecosystems.

\section{Acknowledgments}

We thank the Brazilian Agricultural Research Corporation (Embrapa, project no. 02.11.05.001) and the National Council for 
Scientific and Technological Development (CNPq, project no. 562.601/2010-4) for financially supporting the research activities, CNPq also for providing PQ fellowships for M.F. Fernandes, R.L.L. Berbara and B.E. Madari and for CAPES for providing the Ph.D. fellowship for F.J.G. Lisboa. Finally, the authors wish to thank Dr. Stephen J. Chapman and an anonymous reviewer for relevant discussions to improve this manuscript as well as Sam Gandy for assistance with English writing reviews.

\section{Appendix A. Supplementary data}

Supplementary data related to this article can be found at http:// dx.doi.org/10.1016/j.soilbio.2014.07.017.

\section{References}

Aliasgharzad, N., Martensson, L.M., Olsson, P.A., 2010. Acidification of a sandy grassland favours bacteria and disfavours fungal saprotrophs as estimated by fatty acid profiling. Soil Biology \& Biochemistry 42, 1058-1064.

Anderson, M.J., 2001. A new method for non-parametric multivariate analysis of variance. Austral Ecology 26, 32-46.

Allison, V.J., Yermakov, Z., Miller, R.M., Jastrow, J.D., Matamala, R., 2007. Using landscape and depth gradients to decouple the impact of correlated environmental variables on soil microbial community composition. Soil Biology \& Biochemistry 39, 505-516.

Bach, L.H., Grytnes, J.-A., Halvorsen, R., Ohlson, M., 2010. Tree influence on soil microbial community structure. Soil Biology \& Biochemistry 42, 1934-1943.

Bardgett, R.D., Jones, A.C., Jones, D.L., Kemmitt, S.J., Cook, R., Hobbs, P.J., 2001. Soil microbial community patterns related to the history and intensity of grazing in sub-montane ecosystems. Soil Biology \& Biochemistry 33, 1653-1664.

Bardgett, R.D., McAlister, E., 1999. The measurement of soil fungal: bacterial biomass ratios as an indicator of ecosystem self-regulation in temperate meadow grasslands. Biology and Fertility of Soils 29, 282-290.

Berthrong, S.T., Jobbagy, E.G., Jackson, R.B., 2009. A global meta-analysis of soil exchangeable cations, ph, carbon, and itrogen with afforestation. Ecological Applications 19, 2228-2241.

Brasil, 1983. Projeto Radambrasil. Divisão de Publicação, Rio de Janeiro.

Cao, Y., Fu, S., Zou, X., Cao, H., Shao, Y., Zhou, L., 2010. Soil microbial community composition under Eucalyptus plantations of different age in subtropical China. European Journal of Soil Biology 46, 128-135.

Carson, J.K., Campbell, L., Rooney, D., Clipson, N., Gleeson, D.B., 2009. Minerals in soil select distinct bacterial communities in their microhabitats. FEMS Microbiology Ecology 67, 381-388.

Carson, J.K., Gleeson, D.B., Clipson, N., Murphy, D.V., 2010. Afforestation alters community structure of soil fungi. Fungal Biology 114, 580-584.

Chessel, D., Dufour, A.B., Thioulouse, J., 2004. The ade4 package-I-One-table methods. R News 4, 5-10.

Diedhiou, S., Dossa, E.L., Badiane, A.N., Diedhiou, I., Sène, M., Dick, R.P., 2009. Decomposition and spatial microbial heterogeneity associated with native shrubs in soils of agroecosystems in semi-arid Senegal. Pedobiologia 52, $273-286$.

Drenovsky, R.E., Vo, D., Graham, K.J., Scow, K.M., 2004. Soil water content and organic carbon availability are major determinants of soil microbial community composition. Microbial Ecology 48, 424-430.

Embrapa, 2009. Manual de análises químicas de solos, plantas e fertilizantes [Manual of chemical analyses of soil, plants, and fertilizers], second ed. Embrapa Informação Tecnológica, Brasília.

Fernandes, M.F., Barreto, A.C., Mendes, I.C., Dick, R.P., 2011. Short-term response of physical and chemical aspects of soil quality of a kaolinitic Kandiudalfs to agricultural practices and its association with microbiological variables. Agriculture, Ecosystems \& Environment 142, 419-427.

Frostegård, Å., Bååth, E., Tunlio, A., 1993. Shifts in the structure of soil microbial communities in limed forests as revealed by phospholipid fatty acid analysis. Soil Biology and Biochemistry 25, 723-730.

Frostegård, Å., Tunlid, A., Bååth, E., 2011. Use and misuse of PLFA measurements in soils. Soil Biology \& Biochemistry 43, 1621-1625.

Giraldo, C., Escobar, F., CharÁ, J.D., Calle, Z., 2011. The adoption of silvopastoral systems promotes the recovery of ecological processes regulated by dung beetles in the Colombian Andes. Insect Conservation and Diversity 4, 115-122.

Gower, J.C., 1971. Statistical methods of comparing different multivariate analyses on the same data. In: Hodson, F.R., Kendall, D.G., Tautu, P. (Eds.), Mathematics in the Archeological and Historical Sciences. Edinburgh University Press, Edinburgh, pp. 138-149.

Grayston, S.J., Campbell, C.D., Bardgett, R.D., Mawdsley, J.L., Clegg, C.D., Ritz, K., Griffiths, B.S., Rodwell, J.S., Edwards, S.J., Davies, W.J., Elston, D.J., Millard, P., 2004. Assessing shifts in microbial community structure across a range of grasslands of differing management intensity using CLPP, PLFA and community DNA techniques. Applied Soil Ecology 25, 63-84.
Grossman, R.B., Reinsch, T.G., 2002. In: Dane, J.H., ClarkeTopp, G. (Eds.), SSSA Book Series: 5 Methods of Soil Analysis Ch2. Soil Science Society of America, Inc. Madison, Wisconsin, USA.

Gleeson, D., Clipson, N., Melville, K., Gadd, G., McDermott, F., 2005. Characterization of fungal community structure on a weathered pegmatitic granite. Microbialgy Ecology 50, 360-368.

Gleeson, D., Kennedy, N., Clipson, N., Melville, K., Gadd, G., McDermott, F., 2006. Characterization of bacterial community structure on a weathered pegmatitic granite. Microbiology Ecology 5, 526-534.

Hamza, M.A., Anderson, W.K., 2005. Soil compaction in cropping systems: a review of the nature, causes and possible solutions. Soil and Tillage Research 82, 121-145.

Hodge, A., 2006. Plastic plants and patchy soils. Journal of Experimental Botany 57, 401-411.

Jansa, J., Mozafar, A., Anken, T., Ruh, R., Sanders, I., Frossard, E., 2002. Diversity and structure of AMF communities as affected by tillage in a temperate soil. Mycorrhiza 12, 225-234.

Kasel, S., Bennett, L.T., Tibbits, J., 2008. Land use influences soil fungal community composition across central Victoria, south-eastern Australia. Soil Biology \& Biochemistry 40, 1724-1732.

Kuo, S., 1996. Phosphorus. In: Sparks, D.L. (Ed.), Methods of Soil Analysis: Chemical Methods (Part 3). SSSA, Madison, WI, pp. 869-919.

Lacombe, S., Bradley, R.L., Hamel, C., Beaulieu, C., 2009. Do tree-based intercropping systems increase the diversity and stability of soil microbial communities? Agriculture, Ecosystems \& Environment 131, 25-31.

Lai, R., Lagomarsino, A., Ledda, L., Roggero, P.P., 2014. Variation in soil C and microbial functions across tree canopy projection and open grassland microenvironments. Turkish Journal of Agriculture and Forestry 38, 62-69.

Lamb, E.G., Kennedy, N., Siciliano, S.D., 2010. Effects of plant species richness and evenness on soil microbial community diversity and function. Plant and Soil 338, 483-495.

Legendre, P., Legendre, L., 2012. Numerical Ecology, third English ed. Elsevier 344 Science BV, Amsterdam. 516 pp.

Lisboa, F.J.G., Chaer, G.M., Jesus, E.d.C., Faria, S.M., Gonçalves, F.S., Santos, F.M., Castilho, A.F., Berbara, R.L.L., 2012. The influence of litter quality on the relationship between vegetation and below-ground compartments: a Procrustean approach. Plant and Soil 367, 551-562.

Lisboa, F.J.G., Peres-Neto, P.R., Chaer, G.M., Jesus, E.C., Mitchell, R.J., Chapman, S.J., Berbara, R.L.L., 2014. Much beyond Mantel: bringing Procrustes Association Metric to the plant and soil ecologist's toolbox. PLoS ONE 9 (6), e101238.

Liu, L., Gundersen, P., Zhang, T., Mo, J., 2012. Effects of phosphorus addition on soil microbial biomass and community composition in three forest types in tropical China. Soil Biology \& Biochemistry 44, 31-38.

Liu, L., Zhang, T., Gilliam, F.S., Gundersen, P., Zhang, W., Chen, H., Mo, J., 2013. Interactive effects of nitrogen and phosphorus on soil microbial communities in a tropical forest. PLoS One 8, e61188.

Mendiburu, F., 2014. agricolae: Statistical Procedures for Agricultural Research. http://cran.r-project.org/web/packages/agricolae/index.html.

Millard, P., Singh, B.K., 2009. Does grassland vegetation drive soil microbial diversity? Nutrient Cycling in Agroecosystems 88, 147-158.

Mitchell, R.J., Hester, A.J., Campbell, C.D., Chapman, S.J., Cameron, C.M., Hewison, R.L., Potts, J.M., 2010. Is vegetation composition or soil chemistry the best predictor of the soil microbial community? Plant and Soil 333, 417-430.

Nelson, D.W., Sommers, L.E., 1996. Total carbon, organic carbon and organic matter. In: Sparks, D.L., Page, A.L., Helmke, P.A., Loeppert, R.H., Soltanpour, P.N., Tabatabai, M.A., Johnston, C.T., Sumner, M.E. (Eds.), Methods of Soil Analysis: Chemical Methods (Part 3). SSSA, Madison, WI, pp. 961-1010.

Oksanen, J., Blanchet, F.G., Kindt, R., Legendre, P., Minchin, P.R., O'Hara, R.B., Simpson, G.L., Solymos, P., Stevens, M.H.H., Wagner, H., 2013. vegan: Community Ecology Package. http://cran.r-project.org/web/packages/vegan/index.html.

Olsson, P.A., 1999. Signature fatty acids provide tools for determination of the distribution and interactions of mycorrhizal fungi in soil. FEMS Microbiology Ecology 29, 303-310.

Peres-Neto, P., Jackson, D., 2001. How well do multivariate data sets match? the advantages of a Procrustean superimposition approach over the Mantel test. Oecologia 129, 169-178.

Ponder Jr, F., Tadros, M., 2002. Phospholipid fatty acids in forest soil four years after organic matter removal and soil compaction. Applied Soil Ecology 19, 173-182.

R Core Development Team, 2013. http://www.r-project.org/.

Reith, F., Brugger, J., Zammit, C.M., Gregg, A.L., Goldfarb, K.C., Andersen, G.L., DeSantis, T.Z., Piceno, Y.M., Brodie, E.L., Lu, Z., He, Z., Zhou, J., Wakelin, S.A., 2012. Influence of geogenic factors on microbial communities in metallogenic Australian soils. ISME Journal 6, 2107-2118.

Rinnan, R., Baath, E., 2009. Differential utilization of carbon substrates by bacteria and fungi in tundra soil. Applied and Environmental Microbiology 75, 3611-3620.

Rodrigues, J.L., Pellizari, V.H., Mueller, R., Baek, K., Jesus Eda, C., Paula, F.S., Mirza, B. Hamaoui Jr, G.S., Tsai, S.M., Feigl, B., Tiedje, J.M., Bohannan, B.J., Nusslein, K., 2013. Conversion of the Amazon rainforest to agriculture results in biotic homogenization of soil bacterial communities. Proceedings of the National Academy of Sciences 110, 988-993.

Rousk, J., Baath, E., 2007. Fungal and bacterial growth in soil with plant materials of different C/N ratios. FEMS Microbiology Ecology 62, 258-267.

Rousk, J., Brookes, P.C., Baath, E., 2009. Contrasting soil pH effects on fungal and bacterial growth suggests functional redundancy in carbon mineralisation. Applied and Environmental Microbiology 75, 1589-1596. 
Strickland, M.S., Rousk, J., 2010. Considering fungal:bacterial dominance in soils-Methods, controls, and ecosystem implications. Soil Biology \& Biochemistry 42, 1385-1395.

Thioulouse, J., Prin, Y., Duponnois, R., 2012. Multivariate analyses in soil microbial ecology: a new paradigm. Environmental and Ecological Statistics 19, 499-520.

Thomas, G.W., 1996. Soil pH and soil acidity. In: Sparks, D.L. (Ed.), Methods of Soil Analysis: Chemical Methods (Part 3). SSSA, Madison, WI, pp. 475-490.

Unger, I.M., Goyne, K.W., Kremer, R.J., Kennedy, A.C., 2012. Microbial community diversity in agroforestry and grass vegetative filter strips. Agroforestry Systems 87, 395-402.

Vallejo, V.E., Arbeli, Z., Terán, W., Lorenz, N., Dick, R.P., Roldan, F., 2012. Effect of land management and Prosopis juliflora (Sw.) DC trees on soil microbial community and enzymatic activities in intensive silvopastoral systems of Colombia. Agriculture, Ecosystems \& Environment 150, 139-148. van Groenigen, K.-J., Bloem, J., Bååth, E., Boeckx, P., Rousk, J., Bodé, S., Forristal, D. Jones, M.B., 2010. Abundance, production and stabilization of microbial biomass under conventional and reduced tillage. Soil Biology \& Biochemistry 42, 48-55.

Wixon, D.L., Balser, T.C., 2013. Toward conceptual clarity: PLFA in warmed soils. Soil Biology \& Biochemistry 57, 769-774.

Wright, R.J., Stuczynski, T., 1996. Atomic absorption and flame emission spectrometry. In: Sparks, D.L. (Ed.), Methods of Soil Analysis: Chemical Methods (Part 3). SSSA, Madison, WI, pp. 65-90.

Zelles, L., 1999. Fatty acid patterns of phospholipids and lipopolysaccharides in the characterization of microbial communities in soil: a review. Biology and Fertility of Soils 29, 111-129.

Zhang, X., Chen, Q., Han, X., 2013. Soil bacterial communities respond to mowing and nutrient addition in a steppe ecosystem. PLoS One 8, e84210. 